\title{
Intraoral Reconstruction with Microsurgical Free Flaps
}

\section{Serbest Fleplerle Ağız İçi Defektlerinin Rekonstrüksiyonu}

\author{
Hakan Uzun ${ }^{1}$, Ozan Bitik², Ela Cömert ${ }^{3}$, Caner Kılıç $^{3}$, Samet Özlügedik $^{3}$, Ümit Tunçel $^{3}$ \\ ${ }^{1}$ Dr. A. Y. Ankara Oncology Training And Research Hospital, Plastic Reconstructive and Aesthetic Surgery, \\ Ankara, Turkey \\ ${ }^{2}$ Hacettepe University Faculty of Medicine, Department of Plastic Reconstructive and Aesthetic Surgery, \\ Ankara, Turkey \\ ${ }^{3}$ Dr. A. Y. Ankara Oncology Training And Research Hospital, Department of Otorhinolaryngology, Ankara, \\ Turkey
}

\section{ÖZET}

Amaç: Yazarlar, tek bir merkezde intraoral bölge için gerçekleştirilen serbest flep rekonstrüksiyonlarını değerlendirmeyi amaçlamışlardır.

Yöntemler: Baş boyun bölgesindeki defektlerin rekonstrüksiyonu için 4 yıllık süre içinde onbir tane serbest doku nakli gerçekleştirildi. Hastalar, defekt lokalizasyonu, uygulanan flepler, komplikasyonlar ve hastanede yatış süreleri açısından değerlendirildi.

Bulgular: Yedi hasta serbest radial önkol flebi ile, iki hasta serbest vertikal rektus abdominis muskulokütan flebi ile, bir hasta serbest transvers rektus abdominis muskulokütan flebi ile bir hasta da serbest fibula osteomuskulokütan flebi ile rekonstrükte edildi. Fleplerin hiçbirinde anastomozda tromboz veya hematom nedeniyle reeksplorasyon yapılmadı. Flep kaybı görülmedi. Mortalite veya major morbidite ile karşılaşılmadı. Ortalama hastanede yatış süresi 21.1 gündü (11-25 gün).

Sonuç: Ağız içi defektlerinin rekonstrüksiyonu için multidisipliner yaklaşım desteklenmelidir. Uzun ameliyat süresi, donör alan morbiditesi ve mikrocerrahi başarısızlığı gibi riskleri olmasına rağmen serbest doku nakilleri birçok kompleks defektin onarımına olanak sağlamaktadır.

Anahtar Kelimeler: serbest flep; intraoral rekonstrüksiyon; mikrocerrahi.

\section{ABSTRACT}

Objective: The authors aimed to evaluate the outcomes of free flap reconstructions performed for intraoral region in a single center.

Methods: Eleven free flaps have been performed for defects of the head and neck over a 4-year period. The patients were evaluated in terms of defects, flaps performed, complications and hospital stays,

Results: Seven patients were reconstructed with radial forearm free flap, one patient was reconstructed with free transverse rectus abdominis musculocutaneous flap, two patients were reconstructed with free vertical rectus abdominis musculocutaneous flap and the remaining one was reconstructed with free fibula osteomusculocutaneos flap. None of the flaps required reexploration for anastomotic thrombosis or hematoma. No flap failure occurred. We did not encounter any mortality or major morbidity. The average hospital stay was 21.1 days with a range from 11 to 25 days.

Conclusions: Multidisciplinary approach should be encouraged for the reconstruction of intraoral defects. The versatility of free tissue transfers allows reconstruction of most complex defects; although it carries significant risks, including longer operative times, donor site morbidity, recipient site complications and microsurgical failure, and longer hospital stays.

Keywords: free flap, head and neck oncology, intraoral reconstruction, microsurgery.

\section{Introduction}

Since the development of free tissue transfer and microsurgical techniques in the 1980s, microvascular free flap tissue transfers have largely become the gold standard for reconstruction of complex head and neck defects ${ }^{1-3}$. One distinct advantage of free tissue transfer is its utility (surface area, volume, vascularity, diversity of tissue type) when compared to local or regional tissue transfer. As a result, a large variety of defect dimensions and locations can be reconstructed, allowing for larger oncologic resections,

Adress for correspondence: Ankara Oncology Research and Training Hospital Plastic Reconstructive and Aesthetic Surgery

e-mali: shakanuzuns@gmail.com

Available at www.actaoncologicaturcica.com

Copyright @Ankara Onkoloji Hastanesi 
improved tissue coverage and lower patient morbidity.

Over time, there have been significant changes in reconstructive techniques, with gravitation towards a narrower set of donor sites and a reduction in complication rates ${ }^{4,5}$. The selection and outcomes of free tissue transfers in head and neck reconstructions were evaluated in this study. Outcomes were based on donor and recipient site and indication for reconstruction. Despite the widespread use of this technique in the head and neck, not all free flap donor sites or recipient sites are equivalent. Furthermore, a single percentile to describe failure rates is misleading. We evaluated patients who presented for a microvascular free flap reconstruction of a complex head and neck defect in order to better understand the potential risks and benefits of each type of free tissue transfer.

\section{Methods}

\section{Patient Selection}

The patients who presented between March 2011 and April 2015 for a microvascular free flap reconstruction of a head and neck defect were included $(n=11)$. The selection of the donor site depended on the defect (cutaneous, soft tissue, or bone), and surgeon preference. Demographic characteristics examined included: surgical indication, duration of hospital stay, and complications.

\section{Results}

\section{Patient and Flap Characteristics}

All of the patients were males with a mean age of 54. Indications for reconstruction included defect following resection of a primary or recurrent malignancy $(75 \%, \mathrm{n}=6)$, a secondary reconstruction $(25 \%, n=5)$. The distribution of microvascular free flaps used for reconstruction of the defects was as follows: radial forearm fasciocutaneous flap (RFFF) $(63,6 \%, \quad n=7)$, vertical rectus abdominis musculocutaneous (VRAM) flap $(18,2 \%, \mathrm{n}=2)$, transverse rectus abdominis musculocutaneous (TRAM) flap $(9,1 \%, n=1)$, and free fibula osteomusculocutaneos flap $(9,1 \%, n=1)$. Ipsilateral facial artery and its venae comitantes were used for microsurgical anastomosis. In one patient contralateral facial vessels were dissected. One patient who previously underwent bilateral neck dissection and radiotherapy required saphenous vein grafts due to the unavailability of facial vessels. Superior thyroid vessels were chosen for anastomosis in that case. One artery and one vein anastomosis were performed for each flap. Aside from rectus flaps, two-team approach was used. The average hospital stay was 21.1 days with a range from 11 to 25 days.

\section{Defect Characteristics}

All of the patients had squamous cell carcinoma. Two patients had cancers located on floor of the mouth (Figure 1). One patient had cancer located over the palatopharyngeal fold which extended to lateral and posterior parts of the tongue. They were reconstructed with free RFFF (Figure 2). Two patients underwent partial glossectomy and functional surgery with RFFF was contemplated. One patient underwent hemimandibulectomy and was reconstructed with free fibula osteomusculocutaneos flap (Figure 3). Four patients required release of adhesions between base of tongue and lower lip. Three rectus abdominis flaps and one RFFF were utilized to create new sulcus and lower lips.
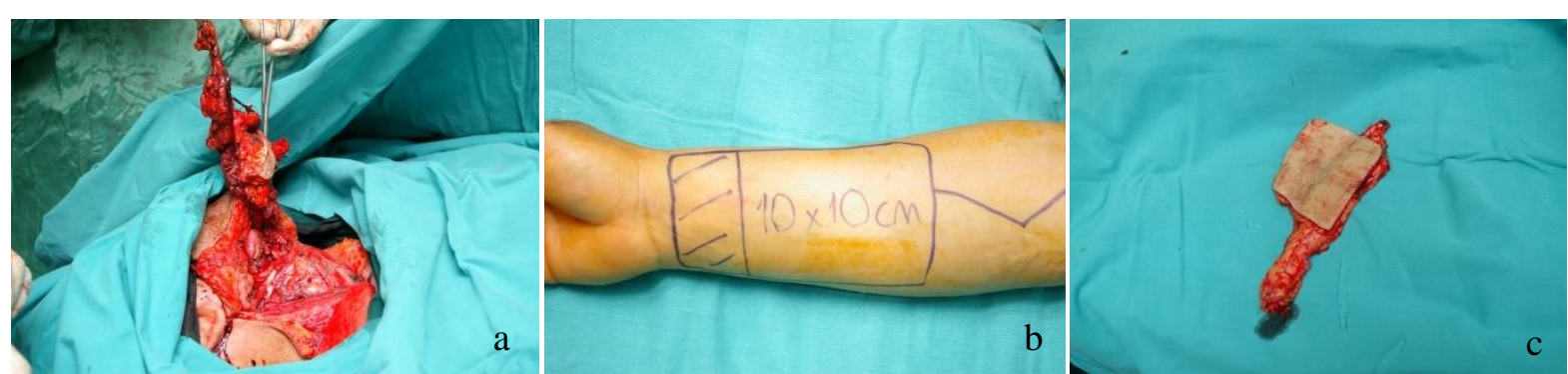

Figure 1a: The defect of the floor of the mouth just before the the specimen was resected en bloc b: Planning of the RFFF c: Harvested RFFF

Adress for correspondence: Ankara Oncology Research and Training Hospital Plastic Reconstructive and Aesthetic Surgery e-mali: shakanuzuns@gmail.com

Available at www.actaoncologicaturcica.com

Copyright @Ankara Onkoloji Hastanesi 


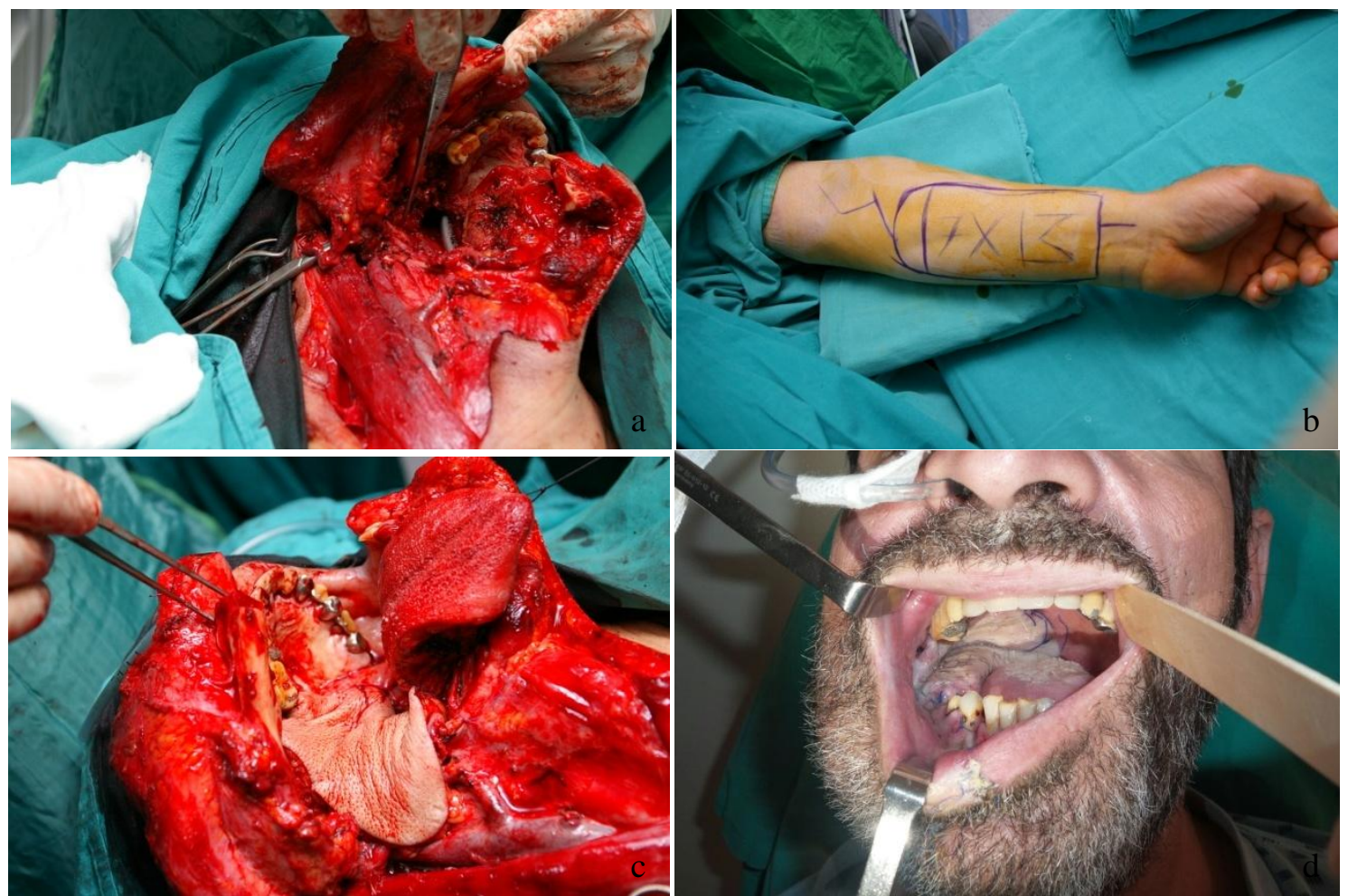

Figure 2a: The 3D defect of the palatopharyngeal region, retromolar region and lateral part of the floor of the mouth exposing carotid vessels.b: Planning of the RFFF c: Insetting of the RFFF d: Postoperative $14^{\text {th }}$ day appearance

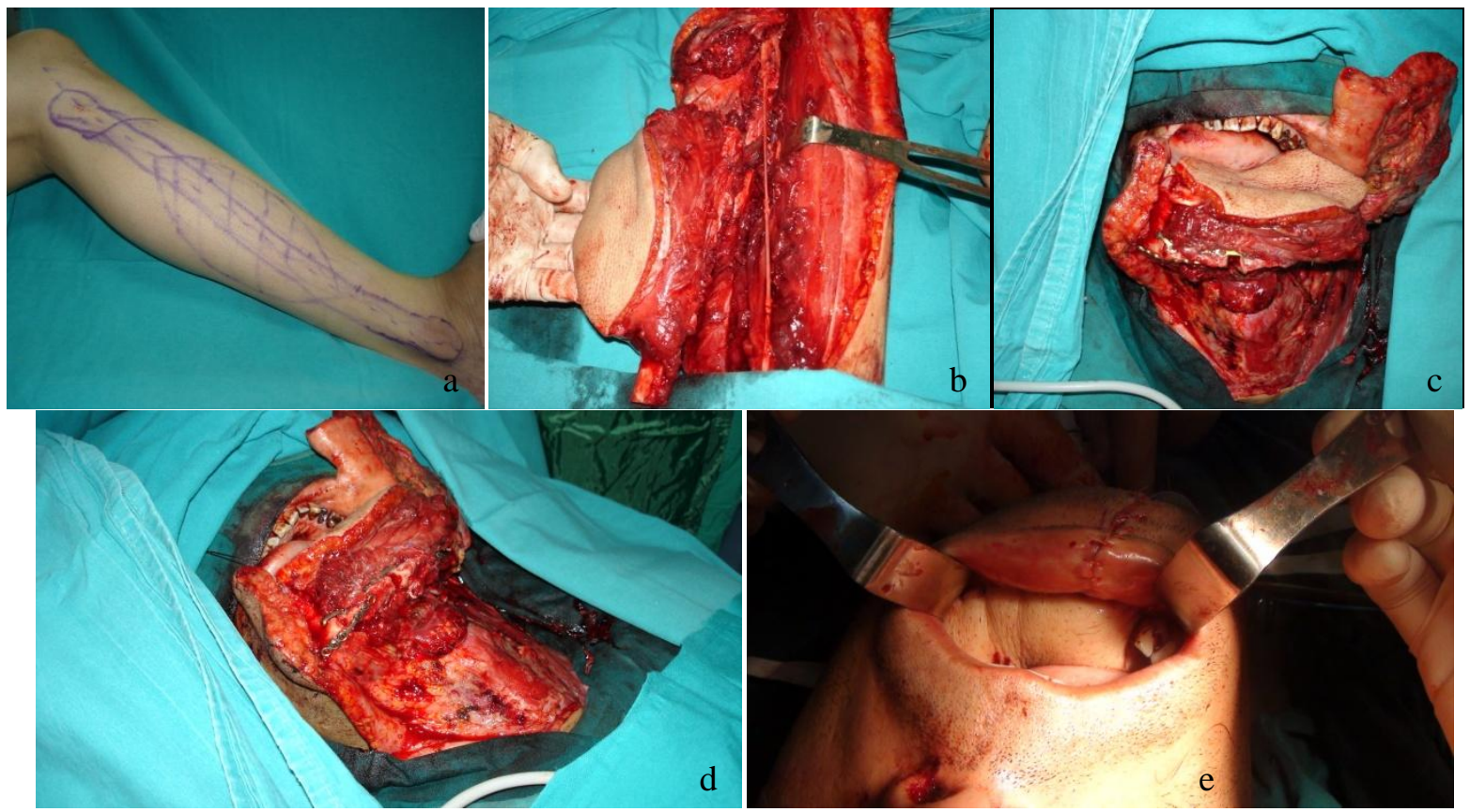

Figure 3a: Planning of the fibula osteomusculocutaneos flap 3b: Harvesting of the flap c: Insetting the skin island of the flap d: Two osteotomies were performed on the flap to create the neoangulus of the mandible e: Early postoperative result

\section{Complications}

All of the free flaps survived. Neither mortality nor major morbidity was developed. None of the flaps required reexploration for anastomotic thrombosis or hematoma. The surgical complication rate was $18,2 \%$. This included haematoma formation under the neck

Adress for correspondence: Ankara Oncology Research and Training Hospital Plastic Reconstructive and Aesthetic Surgery e-mali: shakanuzuns@gmail.com

Available at www.actaoncologicaturcica.com

Copyright @Ankara Onkoloji Hastanesi 
flaps $(9,1 \%, \mathrm{n}=1)$, and graft infection at the donor area of the fibula flap $(9,1 \%, \mathrm{n}=1)$.

\section{Discussion}

The versatility of free tissue transfers allows reconstruction of most complex defects; however, it carries significant risks, including longer operative times, donor site morbidity, recipient site complications and free flap failure, and longer hospital stays. As a result, careful consideration and evaluation is necessary prior to reconstruction. Several variables dictate donor site selection including tissue composition, extent of defect, distance from recipient vessels, and surgeon preference.

The most commonly utilized flap in our series was the RFFF. In 1981, Yang et al were among the first to use the radial forearm flap in head and neck surgery, and this RFFF is nowadays a workhorse in reconstructive head and neck surgery. The RFFF along with the anterolateral thigh flap (ALT) can be considered the workhorses for reconstructing upper aerodigestive tract defects $^{7}$. It is commonly used for tongue, floor of mouth, lip and hard palate reconstruction. Its greatest advantage is the thin and pliable nature of the flap ideal for intraoral soft tissue lining defects. Its ease of harvest and long pedicle (about 20 $\mathrm{cm})$ with large caliber vessels makes it popular with beginners. It can be harvested by twoteam approach. Other advantages are the presence of large diameter superficial veins (cephalic or basilic) and deep venous system (the venae comitantes). Studies have shown that the smaller venae comitantes give reliable venous outflow but due to their smaller caliber, anastomosis is difficult compared to the cephalic vein ${ }^{8}$. There still is a debate regarding which is the dominant venous system. Ichinose et al. ${ }^{9}$ used Doppler to demonstrate the venae comitantes to be dominant. They theorized that interruption of small superficial venous channels draining into cephalic vein during flap harvest would force venous drainage more into the deep system. In our series we used a more clinical way of judgment. After flap harvest, the artery was anastomosed first and venous return was noted from both the superficial and deep systems. Whichever had a faster outflow was used for anastomosis.
Bianchi et al. ${ }^{10}$ and Kesting et al. ${ }^{11}$ reported several advantages of the ALT flap for head and neck defects, including versatility, short harvesting time, and donor site morbidity. However, Kesting et al. ${ }^{11}$ reported that intra-operative arterial spasms occurred more often in the case of the ALT free flap than in the case of RFFF.

Because of its safety, versatility, and predictable anatomy, the VRAM has become a work horse flap for reconstruction throughout the body and within the head and neck region $^{12}$. It has an unparalleled safety record with the lowest vessel thrombosis and flap failure rates ${ }^{13}$.The flap has a lengthy vascular pedicle for anastomosis to either side of the neck and the large caliber of the inferior epigastric vessels makes microsurgical coaptation straightforward. Primarydonor-site closure for very large VRAMs can be achieved without the need for mesh or an additional skin graft. The remote location from the head and neck region saves operative time by permitting simultaneous flap elevation while the ablative portion of the procedure is performed. Patients with oropharyngeal cancer have generalized cachexia in addition to soft tissue deflation from neck dissections and prior radiation. Although native neck tissues are generally thin, the extra volume provided by both the rectus muscle and subcutaneous tissue of the VRAM fills this contour deformity, replaces unstable irradiated tissues, and provides coverage of the large neck vessels.

Fibula MFF was first introduced for OMF reconstruction by Hidalgo and is now considered as the gold standard for mandibular reconstruction ${ }^{14}$. The advantages of fibula include the length of bone available (around $25-30 \mathrm{~cm}$ ), which permits multiple osteotomies and provides adequate pedicle length even for maxillary reconstruction. The peroneal artery and vein are usually of good quality and caliber and ideal for anastomosis to the neck vessels. Due to the distance from the recipient site, two team approach can be used thus greatly reducing operative time.

Our study has several limitations. First, the sample size of our study was small compared to that of the other studies on this topic. Second, we could not evaluate the outcomes in terms of functional aspects and 
patients satisfaction.

Radical resection of tumors of the head and neck with immediate reconstruction by microsurgical free tissue transfer followed by adjuvant radiation therapy provides the best possible chance for cure and functional and social rehabilitation of the patient.

\section{Conflict of Interest: None}

\section{References}

1. Nakatsuka T, Harii K, Asato H, et al. Analytic review of 2372 free flap transfers for head and neck reconstruction following cancer resection. J Reconstr Microsurg 2003; 19:363-368. discussion 369

2. Rinaldo A, Shaha AR, Wei WI, Silver CE, Ferlito A. Microvascular free flaps: a major advance in head and neck reconstruction. Acta Otolaryngol 2002; 122:779-784

3. Seidenberg B, Hurwitt ES. Immediate reconstruction of the cervical esophagus by a revascularized isolated jejunal segment. Surg Forum 1958; 9:413-416

4. Rosenthal E, Carroll W, Dobbs M, Scott Magnuson J, Wax M, Peters G. Simplifying head and neck microvascular reconstruction. Head Neck 2004; 26:930-936

5. Disa JJ, Cordeiro PG. Mandible reconstruction with microvascular surgery. Semin Surg Oncol 2000; 19:226-234

6. Yang GF, Chen PJ, Gao YZ, et al. Forearm free skin flap transplantation: a report of 56 cases. 1981. Br J Plast Surg 1997;50:162Y165

7. Lueg EA. Th e anterolateral thigh $\mathrm{fl}$ ap: Radial forearm's "big brother" for extensive soft tissue head and neck defects. Arch. Otolaryngol Head Neck Surg 2004;130:813-8

8. Lim $\mathrm{YS}^{1}, \mathrm{Kim} \quad \mathrm{JS}^{1}$, Kim $\quad \mathrm{NG}^{1}$, Lee $\quad \mathrm{KS}^{1}$, Choi $\mathrm{JH}^{1}$, Park $\quad \mathrm{SW}^{2}$. Free Flap Reconstruction of Head and Neck Defects after Oncologic Ablation: One Surgeon's Outcomes in 42 Cases. Arch Plast Surg 2014 Mar;41(2):148-52

9. Ichinose $A^{1}$, Terashi H, Nakahara M, Sugimoto I, Hashikawa K, Nomura T, Ogata N, Yokoo $\mathrm{S}$, Tahara S. Do multiple venous anastomoses reduce risk of thrombosis in free-flap transfer? Efficacy of dual anastomoses of separate venous systems. Ann Plast Surg 2004 Jan;52(1):61-3

10. Bianchi B, Ferri A, Ferrari S, et al. The free anterolateral thigh musculocutaneous flap for head and neck reconstruction: one surgeon's experience in 92 cases. Microsurgery 2012; 32:87-95

11. Kesting MR, Holzle F, Wales C, et al. Microsurgical reconstruction of the oral cavity with free flaps from the anterolateral thigh and the radial forearm: a comparison of perioperative data from 161 cases. Ann Surg Oncol 2011;18:1988-94

12. Matros E, Cordeiro P. Single-Stage Reconstruction of Composite Central Neck Defects With the DoubleIsland Vertical Rectus Abdominis Musculocutaneous Flap. Ann Plast Surg 2011;66: 164-167

13. Kroll SS, Schusterman MA, Reece GP, et al. Choice of flap and incidence of free flap success. Plast Reconstr Surg 1996;98:459-463

14. Urken ML, Buchbinder D, Weinberg H, Vickery C, Sheiner A, Parker R, et al. Functional evaluation following microvascular oromandibular reconstruction of the oral cancer patient: A comparative study of reconstructed and non reconstructed patients. Laryngoscop 1991;101:935-50 